\title{
HOW AND WHERE SHOULD WE INVEST IN EUROPE? AN ECONOMIC GEOGRAPHY OF GLOBAL FINANCE
}

\author{
Gordon L Clark and Dariusz Wójcik \\ Said Business School and School of Geography and the Environment \\ University of Oxford, Mansfield Rd., Oxford OX1 3TB,United Kingdom \\ Email: dariusz.wojcik@jesus.ox.ac.uk
}

\begin{abstract}
For some, global finance is ubiquitous and penetrates into every corner of the world. In this case, the growth of advanced electronic communications coupled with top-down investment strategies has provided institutional investors entry into even the most sheltered of capital markets including those of continental Europe. By contrast, many economic geographers find this view of the world both simplistic with respect to the persistence of nation-state's very different regulatory traditions and highly misleading as to the most successful strategies for investing in continental Europe. In this paper, we provide evidence to support these claims, concentrating upon the issue of whether portfolio investment ought to be sectoral and top-down in orientation (assuming nationstates now matter less than ever before) or country-based and bottom-up in orientation (assuming that there continue to be reasons for taking geography seriously). The geography of market information is our point of departure, illustrated by reference to the evidence on rates of return to different kinds of investment strategies and by reference to the apparent informational content of stock market prices for two German companies Mannesmann (now Vodafone) and BMW (representatives of rather different regional models of capital accumulation). In more detail, we report the results of statistical analyses of the volatility of daily stock market prices for German DAX 30 and DAX 100 firms, arguing that their apparent characteristics have important lessons for the value and significance of bottom-up portfolio investment strategies. These results combined with the case studies of the two German firms are used to suggest that the geography of finance remains a vital component of global finance, an argument which has important implications for academic analysis as well as investment strategy.
\end{abstract}

Acknowledgements. Support for this paper was provided in part by an EU $5^{\text {th }}$ Framework grant on comparative corporate governance directed by Mary O'Sullivan and William Lazonick at INSEAD (France). As well, project funding by the ESRC Future Governance programme directed by Edward Page and involving Adam Tickell helped support portions of this work on German regulation and its transformation. It draws upon data provided, in part, by Morgan Stanley Dean Witter through the good offices of Alan Rubenstein and Gareth Derbyshire as part of Dariusz Wójcik's DPhil research project. We are also thankful to Jarek Golacik of Centaurus Capital, London, for the data on German stock prices, and to Jens Widdra of the Bundesaufsichtsamt für den Wertpapierhandel, Frankfurt am Main, for data on the ownership of German companies. None of the above should be held responsible for any errors, omissions, or opinions expressed herein. 


\section{Introduction}

We are all familiar with the "end of geography" thesis as applied to capital markets. In essence, it is supposed that advanced telecommunications, electronic trading systems, and the globalisation of market agents are such that "in today's financial systems it is possible to have markets ... that do not have a geographical location." This quotation could come from any number of academic and policy-related commentators. See, for example, O'Brien's (1992) argument and the related literature in economics and geography (surveyed by Laulajaenian 2000 and Tickell 2000). As it happens, it is the opinion of Willem Duisenberg (2001) President of the European Central Bank. However, for all the strong claims made on its behalf there are many who dispute its reality. Putting aside for one moment the theoretical arguments of geographers (Clark and O'Connor 1997), institutions such as the Bank of International Settlements (Schulte and Violi 2001) have identified significant long-term and systematic barriers to the formation and efficient performance of a single capital market in Europe and beyond.

Even so, European economic integration, the formal and not so formal incorporation of eastern Europe into the EU, and the promotion of a single market designed to rival North America challenge received wisdom. There is little doubt that European nation-states are increasingly vulnerable to European and global capital markets; it is obvious that the pricing of the Euro on global stock exchanges represents an important instance of increasing capital market integration even if there may be widespread disagreement about the Euro's attributed value and movements over time against other currencies. If it was simply an issue of currency trading within and between markets, economic geographers may have less to say about the matter than other specialists. But there are important themes that deserve our attention, most significantly the issue of how and where we should invest in Europe. Institutional investors and their portfolio managers around the world are confronted time and again with a basic question: should investment strategies be based upon countries (assuming the continued segmentation of capital, labour and commodity markets) or sectors (assuming that sectoral integration across borders now dominates the past)?

The proponents of investment strategies based on sectors believe that stock prices are now (or at least will be soon) determined to a larger extent by factors common to company's industry than by the factors born in the country of a company's origin or listing. For example, the stock price of FIAT should behave more similarly to the prices of other car manufacturers than to those of other Italian non-auto companies. This view assumes that companies engaged in the same type of activities are subject to European and global competition which transcends borders. By this logic, knowledge of a country's economic conditions is unlikely to help investors improve their performance. In fact, there are arguments to the effect that neither sector- nor country or even 
company-specific information can improve investment performance. It is argued that all information affecting a stock price is built into the quoted stock prices almost instantaneously (Fama 1991). In other words, capital markets are informationally efficient. The implication of this philosophy for investment management is that instead of collecting information to beat the market, investors should use passive index-based strategies to obtain the average market return. How and where to invest in Europe translates into more complicated questions about the level of integration and informational efficiency of capital markets.

In this paper we tackle these questions by collecting the evidence at the intersection of the disciplines of finance and geography. In addition, we combine financial data with research on the geography of the German capital market in order to highlight the relationship between market integration and efficiency. We argue that the level of integration and efficiency of the capital market in Europe is low. Information on corporate affairs is far from ubiquitous and even professional investors still benefit from searching for information, analysing it more intensely while locating themselves closer to the sources of information. The case of Germany shows that not only countries' borders but also regions matter for the issue of market transparency and efficiency. Fragmentation and inefficiency of the capital market are reflected in the structure of the investment management industry, with an overwhelming majority of European funds being managed actively. The paper shows that the major reason for this common practice is the existence of nation- and region-specific financial alliances and institutions. Consequently, the viability of an active strategy for the future depends on how slowly these alliances and institutions will break down for the sake of an integrated market.

The structure of the paper is as follows. In the following section we present our methodology given the existing research on the geographies of finance. Section 3 introduces the basic issues of investment theory such as market efficiency and its relationship with integration. It also outlines the effects both of these phenomena can have on investment strategies. In section 4 we present evidence on the factors affecting market integration and efficiency in Europe, focusing on the role of information and market transparency. Section 5 analyses in detail the structure of the German stock market. The implications of the findings on market integration and efficiency for the current state and the future of investment management in Europe are described in section 6. Section 7 summarizes the findings and links our results to recent debate about path dependence. In sum, the paper shows there is a systematic negative relationship between European stock price volatility and ownership concentration - a relationship previously understood in specific examples as opposed to the performance of whole capital markets. 


\section{The geography of finance}

There is a massive and growing literature devoted to global finance. Much of this literature is to be found in the cognate disciplines of economics, finance, and comparative corporate governance (Barca and Becht 2001). In geography, however, the topic has been less studied in detail than it has been critically discussed. This is changing, and changing quickly, as is evident in the proliferation of articles and papers in the relevant journals. See for example, papers by the Laulajainen 2001 on the implications of global electronic trading platforms for nation-state stock markets, and Clark and Wójcik (2001) on the role of local knowledge in driving stock market adjustment to global financial crisis. For geographers, the presumption is that geography matters-the trick, however, is to show how and why this is true given presumptions commonly broadcast in the media and elsewhere that geography has evaporated in the face of global financial imperatives.

There are many ways of approaching the topic. Here, we emphasise three shared between geography and related disciplines. One way to proceed would be to document the flow of finance around the world through time and space. In this instance, we could create an atlas of flows drawing on official data available from institutions such as the Bank of International Settlements and the World Bank just as we might link-up those flows to the 24-hour trading clock and the significance of markets such as Tokyo, London, and New York (in that temporal order). Time and space, flows and trades, moments of overlap and moments of accountability within and between financial institutions across time and space are essential points of reference in understanding financial flows (Clark 2003). These are also essential points of reference for corporations and regulatory institutions as they follow the actions of individuals and their trading partners (witness the acts of subversion by so-called "rogue traders" located in firms such as Barings-Singapore and Allied Irish Bank-Baltimore). The geography of time is a natural complement to this kind of analysis, one that is increasingly recognised as such in cultural studies (Galison 2000).

Another way of proceeding is to focus upon the role and significance of hard borders in segmenting financial systems. For instance, we could emphasise the distinctive legal traditions that divide the world into very different regulatory and financial systems (see the work of La Porta et al. 1997, 1998 and his colleagues). At issue here is the extent to which national borders segmenting financial systems are deeply embedded in the global flow of funds, and the extent to which these borders persist in the face of accelerating countervailing imperatives of integration and harmonization. See, for example, recent work on the implications of the harmonisation of international accounting standards for the continuity of nation-state institutions and their matching social and economic relationships (Clark, Mansfield, and Tickell 2002). If geography is taken 
seriously in this manner, it is an issue that has gained increasing significance as it has come to be realised that the origin and transmission of global financial crises may be located, in part, in the coexistence of very different financial regimes and their related behavioural and institutional imperatives (see the various reports on the Asian crisis).

The third way of proceeding and that which is followed here would be to analyse the nature and processing of market information, emphasising the spatial and temporal heterogeneity of information. In finance, it has been argued time and again that markets are informationally efficient: by the logic of the efficient market hypothesis, the only surprises are to be found in new information that is neither systematic in its origin nor systematic in its timing. Otherwise, or so the argument goes, these events would be priced into market expectations and discounted as a consequence (see Fama 1991 for a review and assessment). In other words, much of economic theory assumes that market information is widely shared amongst market actors and is only significant when market agents are surprised by exogenous shocks. By contrast, many studies in geography point to the existence of local, intimate, and often highly differentiated networks of market gossip that translates into differentiated patterns of expectations within and between markets (see, for example, Amin and Thrift 1992 on the City of London). Importantly, financial theorists and leading financial institutions have also come to recognise that information and expectations can be highly differentiated within and between markets, witness the work of Shleifer (2000) and his colleagues on the co-existence of different kinds of market traders in the most "efficient" stock markets of the world.

In fact, the geography of finance can be directly traced to earlier work in geography by Alan Pred (1977) and others on the circulation of information within city systems and the more recent work by Manuel Castells (2000) on networks and communication in post-modern societies. By implication, information is systematically channelled rather than universally shared relying upon formal and not so formal mechanisms of transfer and transmission. Even so, we should acknowledge that there is more information available now than ever before to any market trader linked-up to global information networks. And it is commonly argued that this being the case, all market traders whatever their location in space and time have access to the information necessary to make decisions about financial trends and expectations. There can be no doubt about the significance of the revolution in access to market information, nor can there be any doubt about the massive volume of real-time transfers of market information between remotely located market agents. But there are real doubts about the relevance of much of this information, just as there are many doubts about the integrity and veracity of this information. Put succinctly, information is not knowledge; we must not confuse the quantity of information available with its quality. 
But notice, this argument is about the nature of information within a market or between very similar types of markets (presumably Anglo-American). It is also very important to recognise that there maybe systematic differences between markets in the nature, quantity and quality of information shared between market participants. For example, in market regimes characterised by a high degree of cross-shareholdings and internal co-operation between financial institutions information may circulate internally before it is transferred or leaks out into third party market institutions. Indeed, continental European market regimes have been quite different from AngloAmerican market regimes in this respect; there is a very different premium attached to the flow of information between market agents. Not only may there be differences between market agents in the quality of information there may be also systematic differences between market agents in their access to the quantity of information necessary to make informed investment decisions. This, we believe, is a most important distinguishing characteristic of market regimes one that is crucial to our analysis of the question "how and where to invest in Europe".

We would also argue that by focusing upon the channelling of information within and between financial markets we are also able to consider the nature of investment practices and market institutions. In doing so, our goal is to take geography seriously but in a way that goes beyond documenting the existence of different regulatory institutions to the interaction between those institutions and the actions of market agents located within and without those markets. Global finance, in this regard, flows across space and time in ways that are managed, not simply absorbed by market participants.

\section{Investment theory and practice}

We have indicated that the issues of market efficiency and integration are the keys to the black box problem: how and where we should invest in Europe. In this section, we introduce basic terms from the theory of finance and the practice of investment management to assist our analysis throughout the paper. We start with the efficient market hypothesis, explain the meaning of active and passive investment management, and proceed to the nature of integration between markets. We finish the section with implications that both efficiency and integration have for the choice of investment strategies in the European context.

According to Fama (1991) an efficient financial market is 'one in which security prices always fully reflect the available information' (see Shleifer 2000 for a discussion). Depending on the scope of information embodied in market prices we can distinguish three versions of the 
efficient market hypothesis. The weak version asserts that stock prices 'already reflect all information that can be derived by examining market trading data such as the history of past prices or trading volume' (Bodie et al. 2002, 342). The semi-strong-form hypothesis states that 'all publicly available information regarding the prospects of a firm must be fully reflected in the stock price.' (343). In addition to past prices and volumes, publicly available information includes data on firms' product line, management, financial standing and earnings forecasts. Finally, the strong version of the efficient market hypothesis states that 'stock prices reflect all information relevant to the firm, even including information available only to company insiders' (343).

Belief in the efficient market, or the lack thereof, has a crucial impact on the choice between two generic types of investment management: active and passive. 'Active management entails an attempt to seek out and purchase misvalued securities, with the implicit assumption that the market is inefficient and that not all information is present in securities prices. Passive management assumes that the market is efficient and hence returns are maximised by 'holding the market'. Reflecting transactions and management costs, active management invariably entails higher fees than passive' (Davis and Steil 2001, 61). In passive management, the objective is to equal the return on a market index. This can be accomplished by "purchasing all of the component securities of the index in identical proportions' or purchasing 'a statistically representative sample of stocks whose combined total return will closely approximate that of the index' (Pozen 1998, 214). Active managers, in contrast, switch between broad asset classes (cash, bonds, stocks), between countries, and between specific stocks or groups of stocks, with the main objective of beating the market return (Ellis 1998).

It is interesting to consider the relationship between active and passive management from an evolutionary point of view. According to a study by ABN AMRO (Betson 2000), the two types of management are to a great extent complementary, and they evolve depending on the maturity of the market. Immature markets are very inefficient and the potential benefits from an active strategy are large. With time, the competition between active managers grows and as the market becomes increasingly efficient, this creates room for passive management. At some point, the competition between active managers forces some of them out of the market. Passive management is never the only strategy pursued by all investors, because the shift from active to passive strategies as well as the exit of some active managers creates opportunities for mispricing. In the last stage in the process, an equilibrium persists where 'there are enough active managers to stop prices going too far from fundamental value, but not too many that there are no mispricing opportunities to justify the cost of fundamental analysis' (IPE 2000, Nov).

In order to assess the viability of different investment strategies in Europe we need to 
account for the international dimension of market efficiency. According to Bruno Solnik (1999, 161) 'the fundamental issue of international market efficiency is often viewed in terms of international market integration or segmentation'. We should acknowledge the fact that an efficient European capital markets presupposes a high level of integration. To see why integration matters for market efficiency let us assume that Europe is a set of perfectly efficient but closed national markets, with no international diversification of financial assets. Say that a listed company in Germany, the shares of which are now traded at 10 Euro, decides to introduce a new technology. This innovation is expected to increase the value of the company by 2 Euro per share. As the German capital market is efficient, all investors will now value the company at 12 Euro per share, and so the share price will increase to 12 Euro virtually immediately.

Let us now assume that before the announcement, the company had one foreign investor, an Italian. Except for this single cross-border investor, the German and the Italian capital markets are assumed closed. He or she comes from the country with an efficient capital market, just like the German one, but speaks no German, and has no access to information about the German company. What happens after the announcement of the innovation in this case? All German investors would value the company at 12 Euro, but the Italian would still value it at 10 and in contrast to German investors would be selling their shares at prices above 10. The share price would not rise as quickly as in the previous scenario, the adjustment would take time. The German investors buying for less than 12 Euro would benefit at the expense of the outside Italian investor. The market would be inefficient. The example shows that the sum of efficient markets will be an efficient market only if the markets in question are integrated. In integrated, efficient European capital markets "capital flows across markets would instantaneously take advantage of any new information' and 'prices of all assets would be in line with their relative investment values' (Solnik 1999, 161).

Figure 1 presents in a simplified way the impact of efficiency and integration on the choice of investment strategies in Europe. We distinguish between the allocation of funds within countries and the allocation of assets between countries. Both types of allocation can be conducted passively or actively. Allocation strategy within a country is determined by the level of efficiency in the country, while the strategy of allocation between countries is determined by the level of integration. The more inefficient a country's capital market, the more likely active investment strategy is viable within this country. The more integrated are national capital markets, the less an investor can benefit from analysing the specific conditions of the involved countries. In an immature market where both efficiency and integration are low, on average an investor benefits from active security selection. This involves a bottom-up strategy of searching for mispriced securities on the basis of a 
wide array of information, starting from the specific circumstances of particular companies, through country specific factor and sectoral considerations.

Imagine now that a big step is undertaken towards the integration of a set of inefficient markets by means of the introduction of a common trading platform on which every investor from any European country can sell and buy securities from any other country at a low cost. This would take us to the upper left part of our figure. Integrated but inefficient markets would imply a European economy as a set of integrated sectors and industries. Security selection would still be viable but it would be based more on the analysis of sectors than countries. In contrast, with a high level of efficiency in poorly integrated national markets, an investor would benefit from identifying mispriced national markets but within these markets would pursue a passive strategy. Finally, a Europe of highly efficient and integrated markets would suggest the most passive and top-down of all strategies - pan-European indexing using one of a variety of index products including the FTSE Eurotop 300.

Interpreting figure 1, we should bear in mind the issue of geographical scale. The image presented in Figure 1 is of European capital markets as a set of national markets; but there are also lower and higher spatial levels relevant for the analysis of efficiency and integration. At a lower level than the national market is a set of regional markets, not necessarily integrated, and not necessarily sharing the same level of efficiency. At a higher level, Europe is a supranational region integrated to a different degree with America, Asia etc. In this paper, we consider all three scales emphasising efficiency and integration within Europe. Another classification of capital markets could be based on the type of financial instruments traded in them. Here, we distinguish first of all between bond and equity markets. This paper focuses on equity markets, arguably the largest and the fastest growing components of European capital markets and also one for which the issues of efficiency and integration are of particular relevance.

\section{European capital market integration and efficiency}

There are numerous barriers to the creation of an integrated and efficient international capital market. Solnik (2000) lists the following major impediments: regulations limiting foreign investment, high costs (incl. brokerage, custody, withholding taxes, data collection and analysis), familiarity with foreign markets, risk perception, and inefficiencies of foreign markets (including small liquidity and the potential for manipulation by local investors). It should be stressed that most of the items on this long list have one common denominator - information. The issues of data collection and 
analysis, familiarity, risk perception, and manipulation by local investors all depend on how information is channelled in and between financial markets. In Europe, the introduction of a common currency, and the alignment of some capital market regulations between countries, have already removed foreign exchange risk within the Euro-zone, and have considerably neutralised the legal limitations on foreign investment. Hence, this is certainly information that deserves most attention as a factor of the European capital market integration and efficiency (see also Danthine et al. 2000)

Financial reports constitute the main source of publicly available information. Financial reporting can adversely affect efficiency and integration in three ways: by being untimely, of poor quality, or by being incomparable between companies. All three problems appear significant in Europe. First, in some countries financial reports are released only a long time after the end of the accounting year. In France, for example, they are commonly delayed by 6 months (Solnik 2000). As regards quality, accounting and disclosure in most of the continental European countries are tailored to the needs of tax authorities and creditors, not investors (Nobes and Parker 2000). Investors are interested in the market values of assets but these are often not transparent due to the dominance of conservative valuation procedures (Schmidt 1998). The lack of transparency refers also to liabilities, in particular to those resulting from pension obligations owed to employees (Clark, Mansfield and Tickell 2001). Additionally, there is still a great diversity of accounting standards applied in Europe. The key issue here is whether investors are able to deal with this diversity. Pope and Rees (1994) found out that when earnings adjustments from UK to US GAAP were announced, they caused a market surprise and had a significant impact on the stock prices of British companies listed in the US. If investors in the arguably most developed capital markets in the world have a limited ability to reconcile financial reports, it is unjustified to expect European investors to have this ability.

In order to be useful for investment decisions, publicly available information has to be processed. Caramanolis-Cötelli (1999) and others studied the relationship between the number of analysts researching a Swiss company and abnormal returns around the date of the publication of the company's financial statements. ${ }^{1}$ Controlling for other factors such as the size of a company, they discovered that the larger was the number of analysts, the lower were the negative abnormal returns. In other words, the more intensely a company was analysed, the less surprising were bad news from this company. This suggests that analysts have some predictive abilities and contradicts the efficient market hypothesis. In a review of capital market research in accounting Kothari $(2001,112)$ reports that 'a large body of research demonstrates economically significant abnormal returns spread over several years by implementing fundamental analysis in trading strategies'. We 
should not overlook the fact that the profession of financial analysts and investment advisors in Europe is still relatively underdeveloped. The pan-European Federation of Financial Analysts' Societies has around 12,000 members (mostly in the UK), while the Toronto Society of Securities Analysts has more than 4,000 members.

In addition to the features of publicly available information and the intensity of its processing, another major factor of inefficiency and fragmentation is non-public or inside information. Aktas and others (2001) provide evidence on the role of inside information on the French market, by studying abnormal returns prior to the announcement of mergers and acquisitions involving French companies in the period of 1995-1999. They reported high abnormal returns starting on average 30 days before the announcement date. Their results indicate the existence of heavy informed trading, hidden orders, and the exploitation of private information. They also report how ineffective the French authorities have been in detecting insider dealing. Out of 148 mergers and acquisitions in 1999, the French Securities Supervision Authority reported only 3 cases of illegal trading. It is worthwhile mentioning that France was actually the first European country to make insider trading illegal in 1970 (Braithwaite and Drahos 2000, 154). Most other countries introduced anti-insider-dealing acts only in the late 1980s. It seems justified to expect that the use of insider information on the capital markets is, though to varying extent, a Europe-wide problem (see also Story and Walter 1997 and Ferrarini 1998).

What facilitates the access to, and the understanding of the ability to make sense of both public and private information, is proximity -- understood not only in physical but also in cultural terms. Every now and again we find evidence that proximity affects the intensity of interactions on capital markets. Examples of these interactions include the global flows of foreign portfolio investment (Portes and Rey 1999), foreign ownership of European corporations (Wójcik 2001), pension fund investments in the UK (Martin and Minns 1995), and interregional corporate ownership in Germany (Wójcik 2002a). Evidence on the significant role of proximity can come even from relatively small capital markets. Grinblatt and Keloharju (2001) showed that Finnish investors are more likely to hold, buy and sell the stocks of Finnish firms that are located closer to the investor. What is more, the Swedish speaking part of the Finnish population was much more than proportionately represented in the ownership and trading of the shares of firms that published their reports in Swedish (in addition to Finnish) and the ones that had a chief executive of Swedish origin. The significance of distance, language and culture was less important among sophisticated investors, such as financial institutions than among households (see also Wójcik 2002b). This evidence seems even more powerful when we realise that Finland is among the leading European countries in terms of the quality of financial reporting as well as in terms of the advancement of 
telecommunications technology.

If geography is important it should be reflected not only in the relationship between proximity and interactions but also between proximity and performance. Shukla and van Inwegen (1995) showed that in the period of 1981-1993 British open-end fund managers investing in the US performed significantly worse than US open-end fund managers investing domestically. More upto-date evidence can be fund in the works of Hau (2001a,b), who researched the trading performance of 756 foreign-based and domestic traders in 11 German blue-chip stocks. All considered traders had an equal access to the electronic trading system Xetra, and all the stocks were included in the Pan-European index DJ Stoxx50. The results show that traders located near corporate headquarters of the traded company outperformed other domestic traders. As Hau stated: 'a plausible explanation is that local traders find it easier to establish and maintain a privileged relationship with a company insider who might communicate information shortly before it becomes public' $(2001 \mathrm{~b}, 20)$. Moreover, despite the financial sophistication of all traders, proprietary trading shows a statistically and economically significant underperformance on the side of foreign traders. Hau's own conclusion is "while exogenous or technological barriers might largely disappear, information heterogeneity of investors is likely to represent an enduring feature of market microstructure with important macroeconomic consequences' (2001a,1).

Hau's hypothesis on the role of proximity between traders and company insiders leads us to a broader issue of the relationship between shareholders and company management, the core issue in corporate governance (Shleifer and Vishny 1997). Europe hosts a variety of corporate governance regimes (Wenger and Kaserer 1998). Simplifying we can divide them into two main groups. One is characterised by dispersed ownership and an arm's length relationship between managers and owners (an open system) prevailing in the UK and Ireland. The main features of the closed system, prevailing in continental Europe, are concentrated ownership and crossshareholdings between related firms (La Porta et al. 1999, Becht and Roëll 1999). The crucial component of corporate governance arrangements is the way in which information circulates between companies and the investing public. In an ideal open system we expect information to be universally shared, while in a closed system it is likely to circulate internally in a network embracing management, the dominant holders of voting rights, and other insiders before it leaks out to outsiders. In other words, the latter system is not transparent, and the degree of transparency can be so limited, that the identity of entities controlling companies is itself hidden from outsiders. Consider that it has taken a long international research project of the European Corporate Governance Network to unveil even the most basic facts on the control of the largest European companies (Barca and Becht 2001). 
Even though the literature is focused on national regimes of corporate governance, the arrangements vary considerably within countries (Höpner 2001, Cooke and Morgan 1998). Here we briefly illustrate the relationship between corporate governance and capital markets with the cases of two German companies Mannesmann (now Vodafone) and Bayerische Motorenwerke (BMW). Mannesmann, headquartered in Düsseldorf, traditionally a leader in German heavy industry, in the 1990s refocused its activities on telecommunications. The company had probably the most diffused and international ownership structure of any German firm, with over $60 \%$ of its shares dispersed among foreigners, including $40 \%$ held by US institutional investors. In February 2000, the company was taken over by the British firm Vodafone, itself widely-held, after what could be considered the most spectacular battle for corporate control Europe has seen so far (Garret 2001). The shareholder orientation was very strong in Mannesmann, with high quality annual reports, profitability goals implemented explicitly in the announced strategy, and managerial compensation aligned with share performance. Importantly, the company was particularly renowned for the quality of its relations with shareholders (Höpner and Jackson 2001).

By contrast BMW is a car manufacturer headquartered in Munich and is controlled by the Quandt family. It does not have any major foreign owners. The company suffered through an unsuccessful takeover of the British Rover company, an investment it withdrew from in early 2000. In terms of orientation towards shareholders, the company is virtually the antithesis of Mannesmann, especially in regard to the low quality of its financial reporting (Höpner 2001). Figure 2 presents the distribution of the daily changes in the stock prices of the two companies over the period between the end of 1996 and the end of 2001. Even though the extreme daily changes in price are much bigger for Mannesmann than for BMW, in the former case a much higher percentage of daily changes are close to zero. In other words, at the end of an average trading day the share price of BMW was more different from the closing price of the preceding trading day. This observation is consistent with our earlier description of how information circulates under different regimes of corporate governance. In brief, when information is more universally shared there is on average lower volatility on the stock market. The systematic relationship between corporate governance and stock market volatility is explored in detail in the forthcoming section.

\section{Capital market integration and efficiency: the German case}

By comparing Mannesmann and BMW, we suggested that there is a relationship between corporate governance arrangements and the volatility of stock prices. In this section we show that 
this relationship is systematic. We address this issue by analysing the constituent companies of the DAX100 German stock market index, with particular focus on companies included in the DAX30. As the nature of the sample and variables plays a crucial part in our argument, we present them immediately below before discussing the results.

The DAX30 or shortly DAX is the index of traded German blue chip companies. It includes the top 30 German companies traded on the Frankfurt Stock Exchange, not only according to their size (market capitalisation) but also on account of their turnover. The next 70 companies, following the constituents of DAX30 in terms of their market capitalisation, are included in the index for mid-capitalisation firms, called the MDAX. Together, the DAX30 and the MDAX form the DAX100 index. The German stock market is highly concentrated. Over the period of 19972001 the DAX30 accounted for approximately $85 \%$ of market capitalisation and $96 \%$ of turnover of the DAX100. The share of DAX30 in the total turnover of all German listed companies exceeded 90\% (Deutsche Börse 2001). The sample of companies analysed in this section covers all companies that were constituents of the DAX100 index as at the end of 2001.

Let us define the variables. The independent variable expresses the character of corporate governance in a company, with the stylised extremes described earlier as an 'open' or 'closed' system. For this purpose we used the concentration of ownership, acknowledged as a central concept in the theory of corporate governance (Morck 2000; Shleifer and Vishny 1997), and a central feature of corporate governance in Germany (Hopt 1998; Wójcik 2002b). We use two basic measures of ownership concentration: the share of the largest holder of voting rights in a company (C1), and the Herfindahl index calculated on the basis of the structure of holdings of major voting rights with the following formula:

$$
H=\sum_{i=1}^{n} S_{i}^{2}, \text { where: }
$$

$n$ - the number of major holders of voting rights in a company,

$S_{i}$ - the share of a holder in the total number of voting rights of a company.

The data on ownership comes from Bundesaufsichtsamt für den Wertpapierhandel (BaWe) in Frankfurt and refers to the major holdings of voting rights. The BaWe compile the data on the basis of notifications of voting rights that listed companies have to publish in order to comply with the Securities Trading Act (Wertpapierhandelsgesetz). Both individuals and institutions are obliged to notify BaWe if their voting rights reach, exceed, or fall below one of the thresholds of 5 , $10,25,50$ or $75 \%$. Note, that this obligation refers to both direct and indirect holdings of voting rights. Indirect holdings involve any situation when an entity controls voting rights from shares that 
it does not own. This may happen, for example, when an entity controls a direct shareholder or has been entrusted with the responsibility for their shares. The advantage of this unique data set is that it allows us to look at the concentration of holdings of ultimate control, not merely shareholdings in companies. In the analysis we use the data on holdings in the considered companies as at the end of 1997. If a company was first listed after that date, we use the data on holdings as at the end of the year when the company was first listed.

Another variable used to express corporate governance arrangements of a company is the Index of Shareholder Value Orientation (SVO) developed by Höpner (2001). It is meant to show whether a company has a pro-active shareholder value policy, and how strong such a policy may be. The index is built using three components: the information quality of annual reports, the quality of investor relations, the implementation of profitability goals and the alignment of managerial compensation with the share price. Höpner calculated the value of the index for 40 largest German companies, based on data from the late 1990s. Even though it implies that the value of the index is unavailable for most of the companies, which are the subjects of our analysis, we still consider it a useful complement to the more crude variables of ownership concentration.

The dependent variable is the volatility of stock prices. We use data on the daily changes in the stock market prices of DAX100 companies for the period between the end of 1996 and the end of 2001. Daily change is defined as the percentage change between the stock price as at the close of trading in the Xetra system on a given day, and the closing price of the preceding trading day. In the analysed period of 5 years, there were 1,261 trading days. The volatility of stock prices is measured with three different statistics describing the distribution of the daily changes: range, standard deviation and kurtosis. The last measure allows us to estimate the extent to which observations cluster around a central point. For a normal distribution the value of kurtosis is 0 . Positive kurtosis means that the observations cluster more, while a negative score means that they cluster less than for a normal distribution. Returning to Figure 2, both Mannesmann and BMW have a more narrow distribution of observations than a normal distribution would imply. However, the distribution for Mannesmann is much narrower which is reflected in the value of kurtosis of 67 compared to 1.8 for BMW. To summarise the discussion on the data, Table 1 presents basic descriptive statistics on all the variables.

Our analysis is not the first attempt to relate market price volatility to ownership concentration. The bulk of research on this issue in financial economics has been influenced by Demsetz and Lehn (1985). Analysing the determinants of ownership concentration in the U.S. they suggested that the less predictable a firm's environment, for example prices, technology, or market shares, the larger the potential benefit an owner can obtain by monitoring the firm. Hence, in firms 
characterised by noisier environments, reflected in a higher standard deviation of stock market returns, we should find a higher level of ownership concentration (see also Prowse 1992; Cladera 1997; and Morck 2000). Our reasoning goes in the opposite direction, starting with corporate governance. As we have suggested earlier, the mode of a company's corporate governance in general, and the degree of ownership concentration in particular, affect the circulation of information which is crucial for the assessment of firm's value. If the circulation of information is internal, as we would expect in a company with higher concentration of ownership, outside investors and agents trading its stocks are more uncertain about the true value of the company. Less agreement on the firm's value and the potential for insider trading would lead to a more volatile stock price.

In order to test the above hypothesis, we regressed the measures of volatility on the measures of corporate governance. The coefficients and the goodness of fit for single factor regressions are reported in Table 2. Separate results are presented for DAX30, MDAX and DAX100. Starting with range, for the DAX100 there is a significant positive relationship between ownership concentration and volatility. However, the measures of ownership concentration explain only about $4 \%$ of the variability in range. The standard deviation of daily price changes also grows with growing ownership concentration. Among blue chip companies, the variability of $\mathrm{C} 1$ and Herfindahl index explains $11 \%$ and $14 \%$ of volatility, respectively. The relationship between ownership concentration and stock price volatility is strongest if we measure the latter with kurtosis. For the DAX30 we obtained significant negative coefficients and goodness of fit of $19.5 \%$ and $15.5 \%$ respectively. In Figure 3 we plotted the values of the volatility and ownership concentration for the DAX30 companies. Kurtosis is significantly higher for blue chips with a stronger orientation towards shareholder value. The SVO Index explains as much as $23 \%$ of the variability of kurtosis. This is very high explanatory power considering that there are many other factors that affect volatility, including external economic conditions, such as interest rates as well as firm-specific factors unrelated to corporate governance (Schiller 1989).

Whatever measures of corporate governance or volatility used, the results for MDAX were insignificant. The probable explanation is the very low liquidity of its constituents. Recall that MDAX accounts for only $4 \%$ of the turnover of DAX100 and $15 \%$ of its market capitalisation. Thus, the average intensity of turnover is almost 4 times lower than for the DAX30. With such 'thin' trading it is not unreasonable to expect no systematic relationship between stock price behaviour and corporate governance characteristics. Turning to our central hypothesis, we have established that the relationship between corporate governance and volatility is weak for range, medium for standard deviation, and strong for kurtosis. This order of the strength of the analysed 
relationships is not surprising. We expect that the sum of the most positive and the most negative daily change of a stock price, over a 5 year-long period of time, reflects 'bold' events such as the announcement of major unexpected losses, new investment projects, mergers and acquisitions etc. Meanwhile, the 'quiescence' of daily prices, expressed with kurtosis, reflects the degree of market saturation with information about companies. Standard deviation of daily changes is affected by both groups of factors, and hence it relates to corporate governance to a higher degree than range but lower than kurtosis.

In the light of the above analysis, the initial story about Mannesmann and BMW sketched in the previous section has been empirically sustained. Here, we take the story further, adding an explicit geographical dimension. Recall that BMW is headquartered in the capital of Bavaria, Munich, while Mannesmann was headquartered in the capital of North Rhine-Westphalia, Düsseldorf. Bavaria and North Rhine-Westphalia are the two largest Länder of Germany. Table 3 presents the main characteristics of corporate governance in all non-financial companies headquartered in the two Länder that are listed on the Amtlicher Handel. ${ }^{2}$ Mannesmann and BMW are remarkably representative of the corporate governance regimes prevailing in the regions of their origin. Bavarian firms exhibit a higher level of ownership concentration and a lower incidence of foreign holdings. In 2001, over $60 \%$ of Bavarian firms had at least one major holder of voting rights from the same Land and in almost $50 \%$ of firms a major holder was a German individual or family. In North Rhine-Westphalia, the respective figures were about $40 \%$ and $30 \%$. In a nutshell, Bavaria has a closed regime of corporate governance compared to North RhineWestphalia. Significant changes have taken place in both Länder, but the difference persists. ${ }^{3}$

The higher volatility of the stock price of BMW in relation to Mannesmann is indicative of the more closed system of corporate governance in Bavaria in relation to North Rhine-Westphalia. Our argument, however, is not just that the borders between Länder are the borders between regimes of corporate governance. We also argue that the conditions that affect corporate governance are place and time-specific and they can be read in the observed patterns and behaviour of stock markets. The two major findings of this section, namely the relationship between corporate governance and stock price behaviour as well as the fact that corporate governance is geographically 'nested', reveal the extent of German (and European) capital market inefficiency and fragmentation. The implications of these findings for the understanding of the present and the insight into the future of European investment management are the subject of the following section. 


\section{Implications for investment management}

We reviewed the factors affecting the efficiency and integration of European capital markets focusing on the role of information illustrated with reference to the structure of the German stock market. Publicly available information is deficient in respect of its timeliness and quality, as seen from the point of view of investors. The diversity of accounting standards impedes the integration of the market for public information and further contributes to inefficiency. Additionally, there is considerable information that never becomes public. Uncertainty about the fundamental value of securities is related to the existence of historically rooted and geographically 'nested' regimes of corporate governance. The German case has shown that closed regimes can to be found at the level of regions within countries. All this evidence suggests that European capital markets have a long way to go in terms of the efficiency of national markets as well as in terms of integration both within and between these markets. The general implication for investment management is that it should be conducted actively in the form of bottom-up security selection.

At a first glance, recommending an active investment strategy may appear out-of-date if not backward. Is not there enough empirical evidence demonstrating that investment managers waste effort and money searching for mispriced securities (Jensen 1969, Sharpe 1970, Fama 1991)? Is not the percentage of the passively managed US institutional and retail funds over $50 \%$ and growing (Jeffreys 2000)? However, we should remember that the research demonstrating informational efficiency and the popularity of passive management refer to the US and UK public equity markets. When American institutions invest abroad, their strategies and performance suggest little belief in and a poor case for the efficiency of international capital markets. A survey of managers of international equity products marketed to US tax-exempt customers carried out by InterSec (a consulting company specialising in international investment) found that $83 \%$ of managers followed an active strategy. Security selection was identified the most important stage of the investment process, and only 3\% of managers used a top-down approach (cited in Solnik 2000, 661). Another study by InterSec, for the 10 years ending in 1998, showed that a median non-US equity manager outperformed the EAFE index by a striking $42 \%$ (ibid., 659 ).

Inefficiency and fragmentation are reflected in the structure of the investment management industry across Europe. In 2000, the percentage of pension funds managed passively was estimated at $20 \%$ for the UK and $12 \%$ for continental Europe (Reid 2000). A survey of the behaviour of investment managers in Germany reported that over $83 \%$ believed that the search for new information and its in-depth analysis were most likely to lead to superior results (Arnswald 2001). Though research on the performance of European investment managers is scarce, there is 
some evidence indicating that such beliefs are more than a matter of wishful thinking. Otten and Bams (2001) demonstrated that domestic mutual funds in the UK, Italy, Netherlands and France on average significantly outperformed relevant domestic market indices. They concluded 'contrary to most US evidence, the majority of European funds seems to be able to find and implement new information to offset their expenses, and therefore add value to investors' (23).

The skills of European active investment managers suggested by the findings of Otten and Bams could be taken even more seriously if we could show that these managers perform consistently over time. Evidence on the persistence of managers' performance in the US is mixed (see e.g. Brown and Goetzmann 1995, or Malkiel 1995). The evidence in Europe, though very scarce again, seems favourable for active management. A recent report by Reuters and Citywire informs that 'in a survey of more than 800 UK fund managers, nearly half of those who achieved top-quartile performance in 2000 managed to repeat the feat in 2001 - twice the proportion that could have been expected if the managers had been picked out at random' (cited in FT 2002, Mar 4). Gruenbichler and Pleschiutsching (1999) found significant persistence studying the performance of 333 funds, holding diversified European equity portfolios, and domiciled in 8 European countries.

The importance of country or even region-specific networks of information, the central finding of this paper, is evident in the practice of European investment management. Institutions that have an established position as insiders in these networks, especially the leading continental European banks, have entered the arena of investment management. In principle, their investment managers should not take advantage of information about companies they analyse or invest into which comes from the rest of the organisation. In order to prevent conflicts of interest there are (or should be) Chinese walls between investment banking and relationship banking arms of these institutions. If this is the case, in practice, it has not been proven (Ferrarini 1998). Meanwhile, investment management firms from outside these networks, and mainly US and UK companies, promote and lobby for the ideal of transparency in corporate affairs. Very recently a group of powerful institutional investors formed an internal network (including Hermes Pensions Management, Morley Fund Managers and TIAA-CREF) to meet chief executive officers of continental European companies and demand the improvement of their corporate governance. In fact, their first targets were German blue chip companies (Targett 2002).

It should be stressed that the viability of active investment strategies does not rule out passive management. In other words, saying that there is a lot of room to 'drive' the market does not imply that nobody can 'follow' the market. Following the European market in the form of indexing poses, however, some serious problems. Indexing assumes investing in securities according to their market capitalisation. In Europe, figures for market capitalisation of companies, 
sectors and countries can be highly misleading for at least two reasons. First, cross-shareholdings between listed companies, so common in continental Europe (Barca and Becht 2000, Wójcik 2002b), imply that market capitalisation is inflated. ${ }^{4}$ Another problem is the issue of free-float i.e. 'the proportion of a company's capital available for trading by the public on a stock market' and thus 'excluding the shares held by the controlling shareholders' (Moles and Terry 1999, 241). The lower the free float, given market a market capitalisation, the higher the risk that by trading a stock an investor can adversely affect its price. The providers of stock market indices, such as Morgan Stanley Capital International have attempted to resolve these problems by identifying crossshareholdings and free-float on a company-to-company basis thereby adjusting the composition of their indices.

Analysing the choice of investment strategies by individual firms we should remember that passive and active management are services offered in a competitive market, and their providers need them to be distinctive. If we went back to Figure 1, for any point on the graph representing a given level of efficiency and integration, we would probably find at least one investment manager that would claim that Europe is exactly at this point. Research by MSDW shows that industry factors are increasingly important and will soon dominate country factors implying the value of a 'top-down' approach (Sharaiha and Ametistiva 2000). ABN AMRO (1999) agrees that research should be organised along industries not countries. Schroder, by contrast, claims that countries are still relevant and that $95 \%$ of global institutional money are still managed according to the traditional country allocation model. HSBC stresses that country-based strategies remain vital as markets differ in terms of corporate governance. Fidelity and Goldman Sachs follow security selection based on the observation that stock-specific factors outweigh by far both country and sector effects (Economist 2001, Nov11).

The diversity of investment strategies is also justified by the fact that European capital markets do not represent one single combination of efficiency and integration. They are not all located in a single quadrant in Figure 1. Industries exposed to particularly intense international competition, for example chemical commodities, are likely to be more integrated than other less exposed sectors such as utilities. ${ }^{5}$ Some countries, such as the UK, Ireland or Netherlands, with more open corporate governance systems and/or a high incidence of international companies, are likely to have more informationally efficient capital markets than other countries such as Italy or Greece. Within national capital markets, stock market segments for small firms are likely to be less efficient than markets for blue chip companies (Clark and O'Connor 1997). An empirical study of European mutual funds by Otten and Bams (2001) showed that the outperformance of funds in relation to indices was most pronounced in the case of funds investing in small capitalisation stocks. 
In the late 1990s, the investment management industry in Europe has grown faster than in any other part of the world (Walter and Smith 2000). Some commentators argued that by the end of 2010 as much as $50 \%$ of funds invested in Europe will be managed passively, about the same percentage as that managed this way presently in the US (Jeffreys 2000). Belief in the fast pace of integration is strong. In a European survey of pension funds' investment strategies by Watson Wyatt, $53 \%$ of managers declared an emphasis on sector-based strategy, and only $26 \%$ on countrybased approach (Robinson 2002). What is more, some believe that sector-based strategies undertaken by investment managers can 'dictate' the developments in the underlying capital markets. Witness Solnik: 'the mere fact that major brokers and investors have decided to focus, within Europe, on industries rather than countries will be a self-fulfilling move' $(2000,268)$. Our evidence on the nature of information in German capital markets suggests that scepticism is needed. The circulation of information is geographically 'nested'. Perfectly integrated and efficient European markets would require nothing less than a breakdown of nation- and region-specific financial alliances and institutions.

\section{Conclusions}

In this paper, we began with the question "how and where to invest in Europe?" The question was posed in this manner so as to bring to the fore two fundamental issues: the most appropriate manner in which to manage the investment process (referencing active versus passive equity strategies), and whether investment ought be sectoral (across the nation states of western Europe) or more explicitly geographical (paying particular attention to the nature and structure of countries' securities markets). Using the German securities market as an example, our conclusion is that significant systematic rewards exist for those institutions and individual investors able to sustain an active and geographically targeted investment strategy. This conclusion stands in contrast to recent experience in Anglo-American securities markets that active investment strategies, over the long term, produce lower net returns than passive index-based portfolios of the entire market. There remain systematic and significant differences between Anglo-American finance markets and continental European finance markets affecting crucial elements of the investment process.

Driving our analysis was a basic presumption: that the flow of information within and between markets is a fundamental determinant of the efficiency of markets and ultimately the prospects for any investment strategy. This presumption is shared amongst geographers, economists, and financial analysts. However, not withstanding the significance of this presumption 
for the theory of global finance (see Clark and O'Connor 1997; Shleifer 2000), few if any previous studies have been able to link together patterns of European stockholder ownership with the measured volatility of corporate stock market prices. Furthermore, we have shown that even within the German securities market there are clearly distinctive regional regimes of open or closed stockholder ownership patterns with consequent implications for the measured volatility (and informational content) of quoted market prices. We have been able to represent the financial image of what many other economic geographers have focused upon, namely the existence of distinctive spatial regimes of production and innovation (see, for example, the work of Christopherson 2002, Cooke and Morgan 1998, and Gertler 2001). In effect, the paper has shown the connection between corporate governance and stock market performance given the underlying structure of firms and their relationships with internal and external stockholders.

At the same time, we should be clear about the significance of these findings for the continuing debate over path dependence, persistence and convergence. Using two firms as illustration, Mannesmann/Vodafone and BMW, it is apparent that there is considerable diversity amongst large quoted German firms as to their informational transparency in relation to the needs and practices of global institutional investors. These case studies are illustrative of rather different regional regimes of corporate governance within the German economy, and suggest that whole blocks of firms are more or less sensitive to the imperatives driving global investors. In effect, as large German firms reach out into the international economy the extent to which they are integrated into institutional investors' active or passive equity strategies depends upon the extent to which information flows are transformed from internally focused to externally focused. Put slightly differently, at issue is the extent to which local internal stakeholders' interests in privileged access to information are supplanted by global shareholders' interests in commonly-accessible market information.

Elsewhere, it has been argued that the German model is hardly an integrated and commonly-shared model as is often assumed by commentators on comparative corporate governance (compare Clark, Mansfield, and Tickell 2002 with Dore 2000 and O'Sullivan 2000). Over the 1990s, enormous pressures were brought to bear upon German firms and their corporate managers by global financial forces prompting far greater informational transparency than ever before. This is apparent in the rapid adoption of international accounting rules after 1998, and the moves of many such firms to adopt the governance practices consistent with their listing on AngloAmerican security markets (Clark, Mansfield, and Tickell 2001). By this logic, while there may have been a German model of corporate governance and financial structure as idealised by many commentators some time ago, the evidence gleaned in our empirical research is such that the 
German model maybe better understood as a set of regional regimes of accumulation more less accessible to global investors and more or less amenable to their expectations regarding shareholder value and shareholder dominance.

Furthermore, in the context of changing federal tax regulations regarding the unwinding of the cross-holding of shares between intimately related firms, it has been shown that whole groups of large German firms have seen the increasing dilution of concentrated local ownership in favour of dispersed national and international ownership consistent with the experience of their competing Anglo-American corporations (Wójcik 2001, 2002). When combined with the apparent incentives for German corporate managers to promote the interests of shareholders as opposed to stakeholders, these kinds of changes in ownership structure and informational transparency suggests that some regions of Germany are increasingly global in orientation as opposed to local in orientation. Here, while recognising that we are documenting trends rather than settled conclusions, we would suggest that the German model is hardly a model at all if that is meant to represent a system of integrated and mutually reinforcing institutions that sustain a particular path of accumulation. In fact, it would seem that there are a number of German models more or less tuned to global financial imperatives. In this regard, our conclusions match those of Berndt (2001) who has similarly suggested that the German model is better understood as a rhetorical device rather than a persistent set of institutions.

Our conclusions are contentious and argumentative. Not all analysts need agree with our implications or conclusions. And there maybe other ways of sustaining the empirical analysis that is at the core of the argument of this paper. We would agree, of course, that German and continental European stock markets are not nearly as informationally transparent and efficient as their AngloAmerican counterparts. The evidence produced in this paper demonstrates how and why an active investment strategy based upon a bottom-up and intensive research strategy is more likely a winning strategy than a passive, top-down index-based strategy as used in the Anglo-American world to measure market efficiency and ultimately the long-term returns to investment management (Clark 2000). Our point, however, is that this fact of life is neither representative of a settled landscape of corporate governance nor is it representative of a commonly-shared conception of how continental Europe ought to be organised. Through our analysis here and elsewhere, we have sought to show that global finance is transforming the local-national-global scale of corporate governance and all that means for the distinctive manner in which regional and national systems of governance have been sustained over the past 50 years. 


\section{References}

Aktas, N., de Bodt, E., Declerck, F. (2001) Is there information leakage around business combinations on the French market? Conference paper, European mergers and acquisitions, corporate restructuring and consolidation issues, Barcelona, 16 March 2002, www.iese.edu/ciif/simposio2002/papers.html.

Amin, A., Thrift, N. (1992) Neo-Marshallian nodes in global networks. International Journal of Urban and Regional Research, 22: 571-87.

Arnswald, T. (2001) Investment behaviour of German equity fund managers: an exploratory analysis of survey data. Discussion Paper 08/01, Economic Research Centre. Deutsche Bundesbank.

Barca, F., Becht, M. (2001) The Control of Corporate Europe. Oxford: Oxford University Press.

Becht, M., Röell, A. (1999) Blockholdings in Europe: an international comparison. European Economic Review, 43: 1049-1056.

Berndt, C. (1998) Ruhr firms between dynamic change and structural persistence: globalization, the 'German model' and regional place-dependence. IBG Transactions, 23: 331-352.

Betson, F. (2000) Where active meets passive. Investment and Pensions Europe, Nov: 57.

Bodie, Z., Kane, A., Marcus, A.J. (2002) Investments. New York: McGraw-Hill.

Braithwaite, J. and Drahos, P. (2000) Global Business Regulation. Cambridge: Cambridge University Press.

Brown, S.J., Goetzmann, W. (1995) Performance persistence. Journal of Finance 50: 678-698.

Caramanolis-Cötelli, B., Gardiol, L., Gibson-Asner, R., Tuchschmid, N. (1999) Are investors sensitive to the quality and the disclosure of financial statements? European Finance Review 3: 131-159.

Castells, M. (2000) End of Millenium. Oxford: Blackwell.

Christopherson, S. (2002) Why do national labor market practices continue to diverge in the global economy? The 'missing link' of investment rules. Economic Geography, 78: 1-21.

Cladera, R.C. (1997) Determinants of ownership structure: a panel data approach to the Spanish case. www.ssrn.com.

Clark, G.L. (2000) Pension Fund Capitalism. Oxford: Oxford University Press.

Clark, G.L. (2003) European Pensions and Global Finance. Oxford: Oxford University Press.

Clark, G.L., Mansfield, D., Tickell, A. (2001) Accounting standards and German supplementary pensions: The emerging framework underpinning global finance. Economic Geography, 77: 250271.

Clark, G.L., Mansfield, D., Tickell, A. (2002) The German social market in the world of global finance: pension investment management and the limits of consensual decision making. IBG Transactions (forthcoming).

Clark, G.L., O'Connor, K. (1997) The informational content of financial products and the spatial structure of the global finance industry. In K.R. Cox (ed.) Spaces of Globalisation: Reasserting the Power of the Local. New York: Guilford, 89-114.

Clark, G.L., Wójcik, D. (2001) The City of London in the Asian crisis. Journal of Economic Geography, 1: 107-131.

Cooke P., Morgan, K. (1998) The Associational Economy: Firms, Regions, and Innovation. 
Oxford: Oxford University Press.

Danthine, J.P., von Thadden, E.L., Giavazzi, F. (2000) European financial markets after EMU: a first assessment. Discussion Paper 2413, Center for Economic and Policy Research, London.

Davis, E.P., Steil, B. (2001) Institutional Investors. Cambridge, Massachusetts: MIT Press.

Deutsche Börse (2001) Leitfaden zu den Aktienindizes der Deutschen Börse. www.deutscheboerse.com.

Duisenberg, W. (2001) Developments in international financial markets. Speech delivered at the inauguration ceremony of the Second Swedish National Pension Fund, Gothenburg, 26 September 2001. www.ecb.int.

Ellis, C.D. (1998) Winning the loser's game. New York: McGraw-Hill.

Fama, E.F. (1991) Efficient capital markets. Journal of Finance, 46: 1575-1617.

Ferrarini, G. (ed.) (1998) The European Securities Markets: Implementing the ISD and Beyond. Dordrecht: Kluwert Law.

Galison, P. (2000) Einsteins's clocks: the place of time. Critical Inquiry, 26: 355-89.

Garret, C.S. (2001) From consensus to conflict? The evolving institutions and values of German political economy and the implications for Europe. Paper presented at the conference of the International Studies Association, 24 February, Chicago.

Gertler, M.S. (2001) Best practice? Geography, learning and the institutional limits to strong convergence. Journal of Economic Geography, 1: 5-26.

Grinblatt, M., Keloharju, M. (2001) How distance, language, and culture influence stockholdings and trades. Journal of Finance, 56: 1053-1074.

Hau H. (2001a) Geographic patterns of trading profitability in Xetra. European Economic Review 45: 757-769.

Hau, H. (2001b) Location matters: an examination of trading profits. Journal of Finance, 56: 1959-1983.

Höpner, M. (2001) Corporate governance in transition: ten empirical findings on shareholder value and industrial relations in Germany. Discussion Paper 01/5, Max-Planck-Institut für Gessellschaftsforschung, Köln.

Höpner, M., Jackson, G. (2001) An emerging market for corporate control? The Mannesmann takeover and German corporate governance. Discussion Paper 01/4, Max-Planck-Institut für Gessellschaftsforschung, Köln.

Hopt, K.J., Kanda, H., Roe, M.J., Wymeersch, E., Prigge, S. (1998) Comparative Corporate Governance: the State of the Art and Emerging Research. Oxford: Clarendon Press.

Jeffreys, P. (2000) Even-handed about indexation. Investment and Pensions Europe, July-August: 79-80.

Jensen, M.C. (1969) Risk, the pricing of capital assets and the evaluation of investment portfolios. Journal of Business, April: 167-247.

Kothari, S.P. (2001) Capital market research in accounting. Journal of Accounting and Economics, 31:105-231.

La Porta, R., Lopez de Silanes, F., Shleifer, A. (1999) Corporate ownership around the world. Journal of Finance, 54: 471-517.

Laulajainen, R. (2000) The regulation of international finance. In G. Clark, M. Gertler and M. 
Feldman (eds) The Oxford Handbook of Economic Geography. Oxford: Oxford University Press.

Laulajainen, R. (2001) End of geography at exchanges? Zeitschrift für Wirtschaftsgeographie 45: $1-14$.

Malkiel, B.G. (1995) Returns from investing in equity mutual funds, 1971 to 1991 . Journal of Finance 50: 549-72.

Martin, R., Minns, R. (1995) Undermining the regional basis of regions: the spatial structure and implications of the UK pension fund system. Regional Studies, 29: 125-144.

Moles, P., Terry, N. (1999) The Handbook of International Financial Terms. Oxford: Oxford University Press.

Morck, R.K. (ed.) (2000) Concentrated Corporate Ownership. Chicago: The University of Chicago Press.

Nobes, C., Parker, R. (2000) Comparative International Accounting. Harlow: Pearson Education.

O'Brien, R. (1992) Global Financial Integration: The End of Geography. London: Pinter.

O'Sullivan M. (2000) Contests for Corporate Control: Corporate Governance and Economic Performance in the United States and Germany. Oxford, Oxford University Press.

Pope, P., Rees, W.P. (1994) International differences in GAAP and the pricing of earnings. In F. Choi, R. Leftwich (eds) International Capital Markets in a World of Accounting Differences. New York: John Wiley.

Portes, R., Rey, H. (1999) The determinants of cross-border equity flows. Discussion Paper 2225, Center for Economic and Policy Research, London.

Pozen, R.C. (1998) The Mutual Fund Business. Cambridge, Massachusetts: MIT Press.

Pred, A.J. (1977) City Systems in Advanced Economies: Past Growth, Present Processes and Future Development Options. New York: John Wiley.

Prowse, S.D. (1992) The structure of corporate ownership in Japan. Journal of Finance, 47: 1121-1140.

Shukla, R.K., van Inwegen, G.B. (1995) Do locals perform better than foreigners? An analysis of UK and US mutual fund managers. Journal of Economics and Business, 47: 241-254.

Reid, D. (2000) Indexing still on growth track. Investment and Pensions Europe, November: 5455.

Robinson, P. (2002) European funds' wider horizons. Investment and Pensions Europe, January: 55.

Schmidt, P.J. (1998) Disclosure and auditing: a German auditor's perspective. In K.J. Hopt, H. Kanda., M.J. Roe, E. Wymeersch, S. Prigge (eds) Comparative Corporate Governance: the State of the Art and Emerging Research. Oxford: Clarendon Press, 743-753.

Schulte, W., Violi, R. (2001) Interactions between cash and derivatives bond markets: some evidence for the Euro area. Bank for International Settlements Papers, 5: 67-113.

Sharpe, W.F. (1970) Portfolio Theory and Capital Markets. New York: McGraw-Hill.

Shiller, R.J. (1989) Market Volatility. Cambridge, Massachusetts: MIT Press.

Shleifer, A., Vishny, R.W. (1997) A survey of corporate governance. Journal of Financial Economics, 52: 737-783. 
Shleifer, A. (2000) Inefficient Markets: An Introduction to Behavioral Finance. Oxford: Oxford University Press.

Solnik, B. (2000) International Investments. Reading, Massachusetts: Addison-Wesley.

Story, J., Walter, I. (1997) Political Economy of Financial Integration in Europe: The Battle of the Systems. Manchester: Manchester University Press.

Targett, S. (2002a) Star managers up for transfer. Financial Times, Fund Management, 4 March: 1.

Targett, S. (2002b) Investors in Europe showdown. Financial Times, 4 February: 15.

Tickell, A. (2000) Finance and localities. In G. Clark, M. Gertler and M. Feldman (eds) The Oxford Handbook of Economic Geography: 230-252. Oxford: Oxford University Press.

Wenger, E., Kaserer, C. (1998) German banks and corporate governance: a critical view. In K.J. Hopt, H. Kanda., M.J. Roe, E. Wymeersch, S. Prigge (eds) Comparative Corporate Governance: the State of the Art and Emerging Research. Oxford: Clarendon Press, 499-536.

Wójcik, D. (2001) Cross-border corporate ownership in Europe is not consistent with an integrated capital market: evidence from portfolio and industrial holdings. Working Paper No. 01-06, School of Geography and the Environment, Oxford University.

Wójcik, D. (2002a) Regions are the building blocks of the German capital market. Regional Studies (forthcoming)

Wójcik, D. (2002b) Change in the German model of corporate governance: evidence from blockholdings 1997-2001. www.ssrn.com.

Figure 1. The choice of investment strategy as a function of market efficiency and integration

Allocation within countries

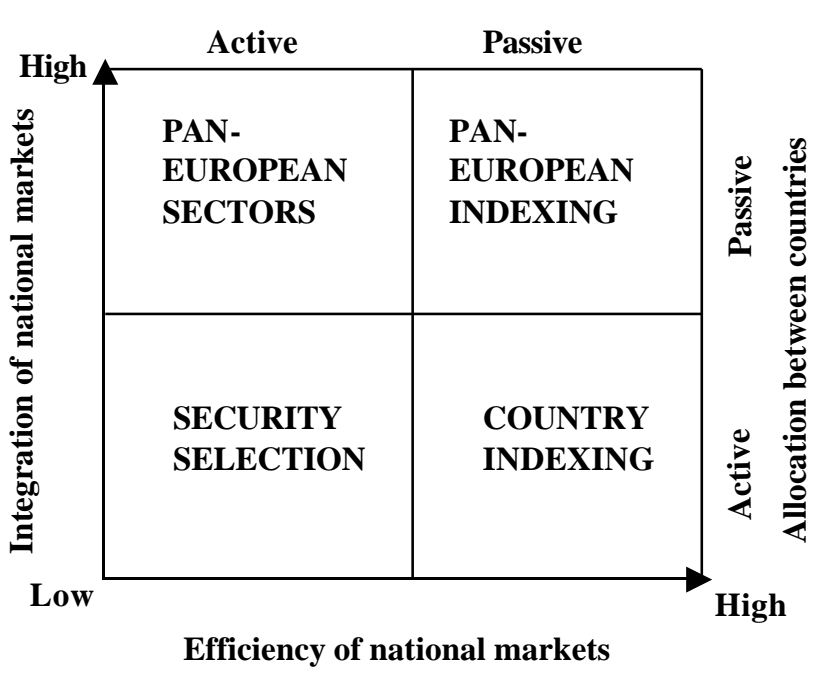


Figure 2. The distribution of daily changes in the stock prices of Bayerische Motorenwerke (BMW) and Mannesmann (now Vodafone) in the period between the end of 1996 and the end of 2001

Number of observations

BMW

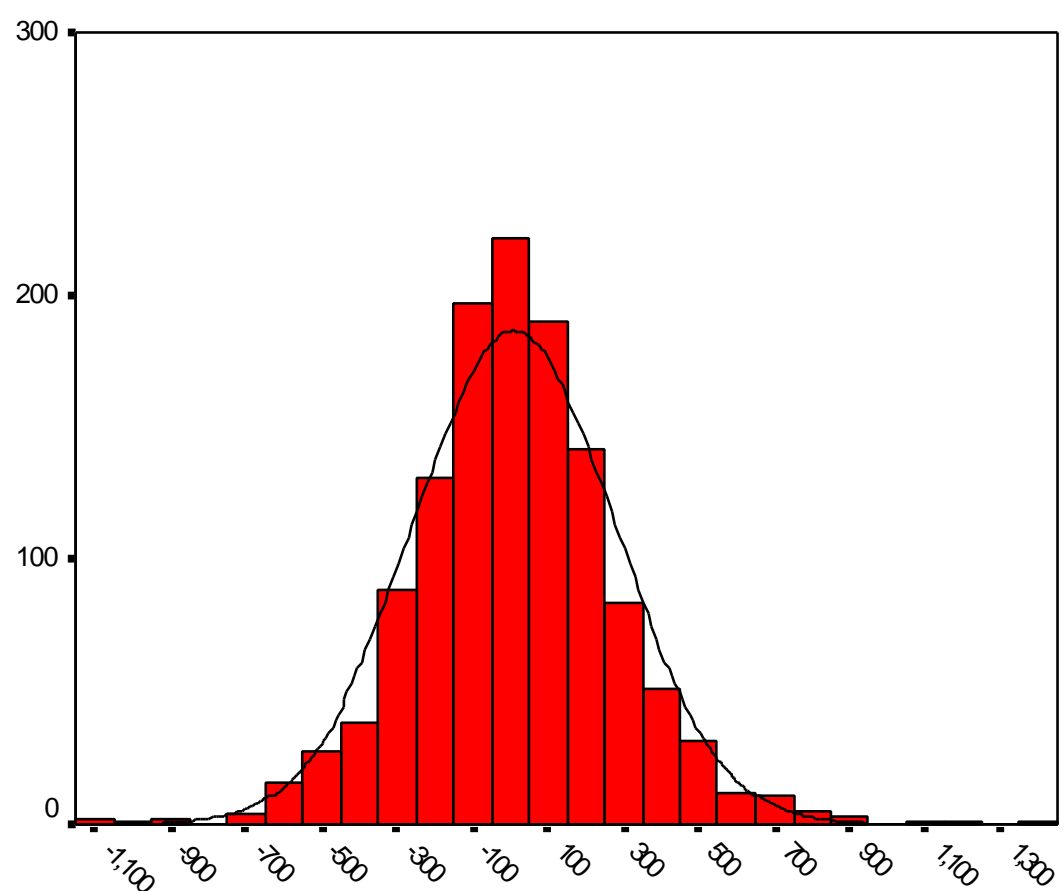

Summary statistics

$\begin{array}{lr}\text { Total number of observations } & 1,260 \\ \text { Minimum } & -1,137 \\ \text { Maximum } & 1,369 \\ \text { Mean } & 10.4 \\ \text { Standard deviation } & 268 \\ \text { Kurtosis } & 1.77\end{array}$

Mannesmann

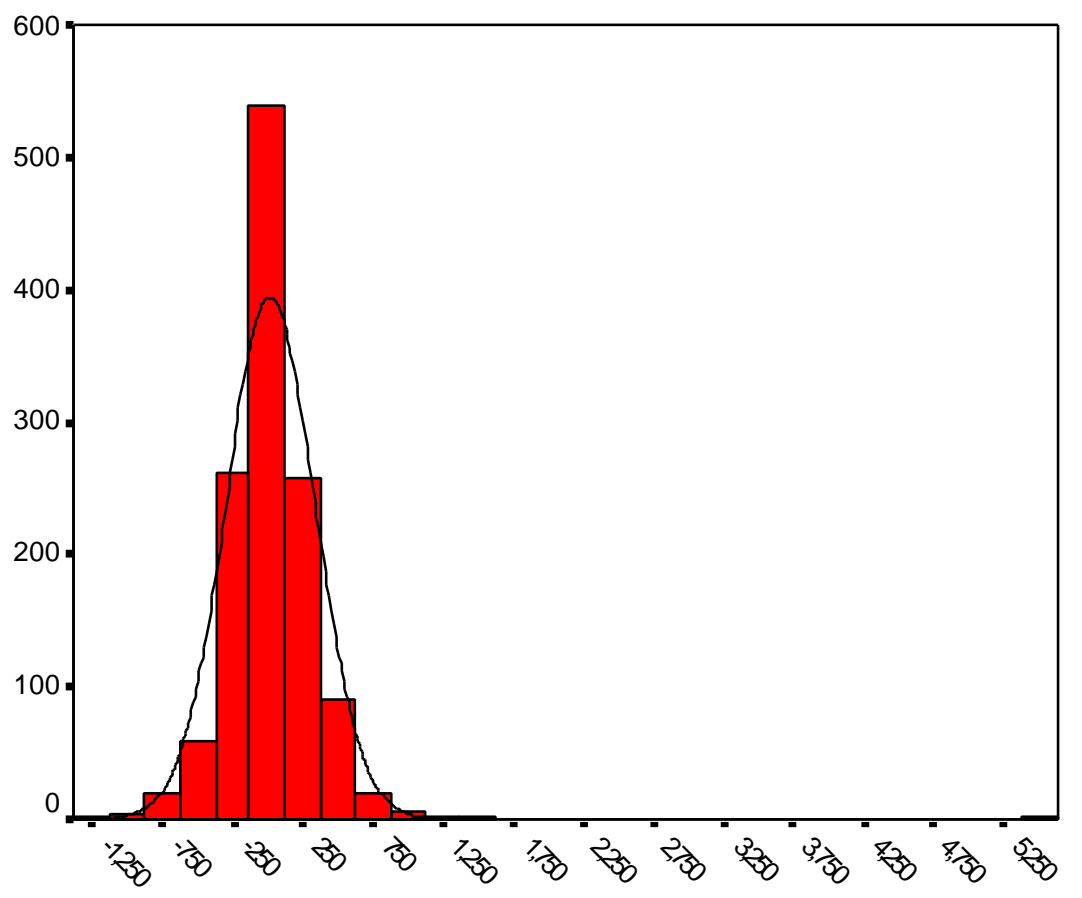

1,261

$-1,133$

5,433

19.2

318

67.01

Source: Authors' calculations based on data from Centaurus Capital, London 
Table 1. Summary statistics for the variables of corporate governance and volatility

\begin{tabular}{lclrrrr}
\hline \multicolumn{1}{c}{ Variable } & $\begin{array}{c}\text { Number of } \\
\text { observations }\end{array}$ & Unit & Minimum & Maximum & Mean & $\begin{array}{c}\text { Std. } \\
\text { Deviation }\end{array}$ \\
\hline C1 & 100 & per cent & 5 & 97.80 & 37.42 & 23.46 \\
Herfindahl & 100 & Index & 0 & 1.17 & 0.24 & 0.23 \\
SVO & 29 & Index & -1.3 & 1.61 & 0.15 & 0.81 \\
Range & 100 & basis point & 1 & 10,618 & 2,886 & 1,495 \\
Standard deviation & 100 & basis point & 119 & 496 & 285 & 81 \\
Kurtosis & 100 & na & 0.68 & 213.31 & 7.29 & 21.40 \\
\hline
\end{tabular}

Source: Authors' calculations based on data from BaWe, Frankfurt; Centaurus Capital, London, and Höpner 2001 
Table 2. Parameters of single-factor regressions of volatility on corporate governance

\begin{tabular}{|c|c|c|c|c|c|c|c|}
\hline \multirow{3}{*}{ Independent variable } & & \multicolumn{6}{|c|}{ Dependent variable } \\
\hline & & \multicolumn{2}{|r|}{ Range } & \multicolumn{2}{|c|}{ Standard deviation } & \multicolumn{2}{|c|}{ Kurtosis } \\
\hline & & Coeff. & Adj. R Square & Coeff. & Adj. R Square & Coeff. & Adj. R Square \\
\hline \multirow[t]{3}{*}{$\overline{\mathrm{C} 1}$} & DAX30 & 1.7 & 0.4 & $0.94^{\star \star}$ & 10.6 & $-2.11 \mathrm{E}-02^{\star \star}$ & 19.5 \\
\hline & MDAX & 10.9 & 3.1 & 0.59 & 2.6 & $9.18 \mathrm{E}-02$ & 0.9 \\
\hline & DAX100 & $11.5^{\star \star}$ & 4.2 & $0.81^{\star \star}$ & 5.6 & 8.80E-02 & 0.7 \\
\hline \multirow[t]{3}{*}{ Herfindahl Index } & DAX30 & 502 & 2.2 & $136^{* *}$ & 14.3 & $-2.23^{* *}$ & 15.5 \\
\hline & MDAX & 858 & 2.1 & 50 & 2 & 3.48 & 1 \\
\hline & DAX100 & $1108^{*}$ & 3.8 & $79^{\star \star}$ & 5.1 & 5.37 & 1.3 \\
\hline \multirow[t]{3}{*}{ SVO Index } & DAX30 & 149 & 2.5 & -4.9 & 0.5 & $0.92^{\star *}$ & 22.8 \\
\hline & MDAX & 125 & 0.6 & -15.2 & 6.2 & 2.84 & 1.6 \\
\hline & DAX100 & -116 & 1.2 & -13.2 & 6.4 & -0.69 & 0.4 \\
\hline
\end{tabular}

Significance of coefficients at $5 \%\left({ }^{* *}\right)$ or $10 \%\left({ }^{*}\right)$

Source: Authors' calculations based on data from BaWe, Frankfurt; Centaurus Capital, London, and Höpner 2001 
Figure 3. Ownership concentration and volatility of stock prices for the DAX 30 companies Volatility (kurtosis)

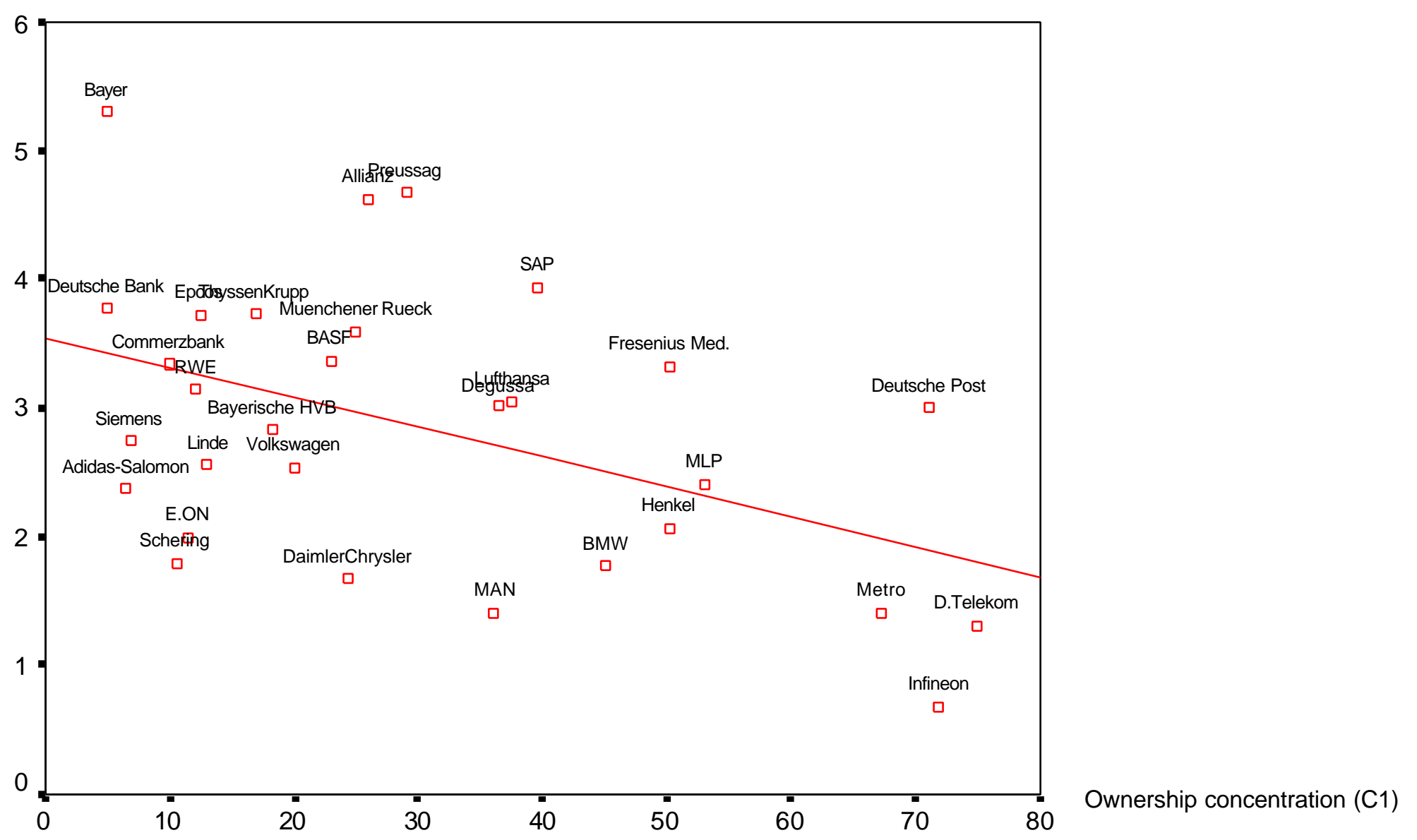

Source: Authors' calculations based on data from BaWe, Frankfurt; and Centaurus Capital, London 
Table 3. Corporate governance characteristics for Bavaria and North Rhine-Westphalia

(For non-financial companies listed on Amtlicher Handel)

\begin{tabular}{|c|c|c|c|c|c|c|}
\hline \multirow[t]{2}{*}{ Variable } & \multicolumn{2}{|c|}{ Bavaria } & \multicolumn{2}{|c|}{ North Rhine-Westphalia } & \multicolumn{2}{|c|}{ Germany } \\
\hline & 1997 & 2001 & 1997 & 2001 & 1997 & 2001 \\
\hline No. of firms & 79 & 79 & 89 & 95 & 321 & 352 \\
\hline \multicolumn{7}{|l|}{ Concentration of holding rights } \\
\hline Median C1 (\%) & 73.1 & 71 & 63.2 & 58.5 & 63.4 & 60.1 \\
\hline Median Herfindahl Index & 0.56 & 0.52 & 0.42 & 0.41 & 0.45 & 0.44 \\
\hline \multicolumn{7}{|l|}{$\underline{\text { Foreign holdings }}$} \\
\hline No. of firms with major foreign holders & 16 & 19 & 20 & 30 & na & na \\
\hline Share of foreign holders in Mcap (\%) & 3.2 & 3.1 & 26.5 & 25.4 & 16.8 & 14.5 \\
\hline \multicolumn{7}{|l|}{ Domestic holdings } \\
\hline No. of firms with major holders from the same Land & 59 & 50 & 50 & 44 & na & na \\
\hline No. of firms with major individual or family holders & 34 & 36 & 31 & 32 & na & na \\
\hline
\end{tabular}

Source: Authors' calculations based on data from BaWe, Frankfurt, and MSDW, London

For a description of Amtlicher Handel see footnote 2 


\section{Endnotes}

${ }^{1}$ Abnormal return is defined as the difference between actual return on a security and the return implied by the level of market return (in this case the return on the whole Swiss stock market) and the security's sensitivity to market return. For details see, for example, Bodie et al. 2002.

2 Amtlicher Handel is one of the four segments of the German stock market, along with Geregelter Markt (regulated market), Freiverkehr (over-the-counter market) and Neuer Markt (new market, opened in 1997 and meant for young growth firms). In relation to geregelter Markt and Freiverkehr, companies listed on Amtlicher Handel have to comply with stricter disclosure requirements. The shares are traded not only on the Frankfurt Stock Exchange, but also on the 7 regional exchanges, in Berlin, Bremen, Düsseldorf, Hamburg, Hannover, München, and Stuttgart. Frankfurt, however, in 2000 accounted for over $80 \%$ of the trading volume.

${ }^{3}$ For the description of the changes in the German model of corporate governance see Berndt 1998, Clark et al. 2002, and Wójcik 2002; for changes in the corporate sector of North Rhine-Westphalia see Berndt 2001.

${ }^{4}$ For an illustration, if two companies own $50 \%$ of each other's equity, their total capitalisation is double the amount of capital they really represent.

${ }^{5}$ Interestingly, Höpner (2001) in his study of 40 top German firms found a positive relationship between a company's exposure to international product market competition and shareholder value orientation. 